\title{
GREATER PRODUCTION IN RELATION TO' HILL-COUNTRY, FARMING
}

\author{
By E. A. MADDEN, Agrostologist, Department of \\ Agriculture, 'Palmerston North.
}

To stimulate discussion I have divided the subject into three sections, the first dealing with grasses and pasture establishment and' maintenance, the second dealing with soil fertility, and the third with finance.

At the outset, one must stress the important role that hill country plays in our primary industries, and we must realise that a balanced national economy demands. greater production from the hill country.

For many years good returns were obtained' from the unploughable back country, but unfortunately much of this land today produces very little, and extensive areas have gone out of production entirely. In the first few years following the felling and burning of the forest the new pastures produced well, but with the reduction in soil fertility pastures deteriorated and second growth became a problem. To a large extent the weakening of the pastures was due to the sowing of unsuitable seed mixtures, mixtures which did not contain truly perennial species as we know them today'. Furthermore, the poorer types of grasses and clovers were not sown as a rule. When the high-producing ones of non-persistent strains died out the pasture opened up and was invaded by weeds. Had the hardier and less productive grasses been included in the original seeds mixtures it is highly probable that they would have spread slowly and filled the gaps.

We must endeavour to improve the existing pastures by establishing in them the grasses and clovers that are suitable to the conditions; we must regrass the hills which have reverted to second growth wherever it can be done economically ; and, lastly, we must consider ways and means of converting forest country to pasture where the nature of the-hills allows it to be done at a reasonable cost in relation to its ultimate, aotentialities. 
During the last 25 years a great deal has been learned about grassing and management of hill country, but there is scope for much further experimentation.

In the same way that the various species of forest , trees grew better in some places than in others, so we must provide a wide range of grasses to suit the diversity of conditions and I am fairly certain that- we have by no means explored the possible value of many grasses for the various classes of hill country.

On easy country,, if a pasture is not satisfactory it can be ploughed and re-sown, but on steep country, 'the ash following a bush or scrub burn is the only seed bed that can be obtained. It is important, therefore, to sow only the best seeds of the most suitable grasses on hill country, and under no circumstances should cheap bush-burn seeds be sown. Because it may be necessary periodically to burn scrub and second growth, fire-resisting species should be included in the seeds mixture and each mixture should be made to suit the soil and climatic conditions.

Trials have been carried out to ascertain how best to establish additional grasses and clovers in existing swards, but further experiments will be necessary before definite conclusions can be reached. Until responsive species, especially clovers, are established in the pastures, the benefits of topdressing may be negligible. So far the most promising ways of establishing clovers on hill country seem to be by sowing seed on the ash following a scrub, fern, or grass fire. Another method, which has proved to be satisfactory is by feeding hay containing mature clover seeds to cattle and then driving them on to the clover-deficient hills so that the seeds will pass out with the excreta.

Management of hill country pastures and the sheep to cattle ratio can be talked of at length, but apart from a few general principles it seems that such matters must be determined by the farmer's experience on his own property. There are two distinctly different lines of thought on grazing management; one involves set stocking with cattle and the moving of sheep in a rotational-grazing system ; the other method requires set stocking with sheep and the moving of cattle from paddock to paddock to clean up roughage. There are virtues in each of these systems, but whichever method is adopted the aim must be to utilise thoroughly all the pasturage that is produced so that there will be a 
better distribution of stock manures over the paddock, thereby producing a more uniform pasture.

The control of fern and hutiwai can be accomplished very largely by good grazing management. Some weeds, variegated thistle for instance, can be dealt with by judicious stocking, pasture improvement, and the use of chemical sprays. Manuka, on the other hand, is a problem which does not appear easy to solve and it seems that much hard work will be needed before manuka is exterminated. There are possibilities that the blight may play a big part in controlling manuka, but it is premature to make any definite statements. about it yet.

Now to deal with the second major point which I mentioned at the start, namely, soil fertility, it must be realised that there are economic limits to which this might be carried. It is probable that low-producing pastures which require little or no maintenance costs may be better on some tracts of country than high-producing ones which are expensive to maintain. This is more particularly true where the costs of topdressing are high in relation to the increased returns which may be obtained.

The aeroplane may alter some' of our ideas about pasture improvement. At present the aerial topdressing industry is progressing, but there are bound to be limits to its expansion. For instance, the quantity of phosphatic fertiliser available may restrict, for some years at least, the area of hill country which can be topdressed. At the present time it appears that all light aircraft suitable for topdressing work will be expended in less than 2 years and the prospects of getting, new aeroplanes at a reasonable price are poor.

In a recent circular from America it was learned that some of the essential materials for the light aircraft industry are to be made available to manufacturers, but even so the production of light aeroplanes is not likely to exceed 3000 per year and all these are needed in America.

There are limitations to the use of large areoplanes for aerial topdressing, as they have not the advantage of being able to fly low and manoeuvre in rough hill country. Furthermore, large aircraft with big loads would have to operate from large aerodromes and then

it becomes a matter of comparing costs of operating such aircraft over long distances with the costs of operating light aircraft from local air-strips plus road 
haulage of fertiliser to those air-strips. The value of phosphate in top-dressing is to stimulate clover growth so that the soil will be enriched in nitrogen because, in general, it is nitrogen which is needed.

Reference to fertiliser supplies and to nitrogenous ones in particular brings to mind the fact that Dr. Bridger, of the Iowa State College, said in his report to our Government recently, "Studies should be made to determine the extent to which nitrogenous fertilisers could be used profitably if they were available at a significantly lower cost. If an electric-furnace doublesuper-phosphate plant is built, facilities for the production, of nitrogenous fertiliser should be included."

In 1928 a survey was made by the Public Works Department of the water resources of the Doubtful Sound area of South Westland with a view to building a generating station for the manufacture of nitrogenous fertilisers. Apparently the scheme was feasible, but the value of nitrogen was not fully appreciated and no further developments took place. It is to be hoped that a decision will be made very soon to produce large quantities of nitrogenous fertiliser in New Zealand.

The third major point demanding thought in connection with hill country is that of finance. Reference to lack of finance was made by $\mathrm{Mr}$ Larsen. I know that many hill country farmers have failed to make a success of their farms through not having enough capital or through having to pay large sums in interest before their properties are really productive. If settlement and development of unproductive hill country is to be achieved, some better system of financing that development seems essential. Alternatively, we could let the hills go back to native forest or plant them in exotic timbers.

Some country is rather too steep for economic afforestation schemes but not, too steep. for sheep and cattle. Tree planting costs money and it is necessary to incur expenditure on forest maintenance for some years and still wait 15 years or more for returns.

If say $1,000,000$ acres of unproductive land can be made to carry one sheep per acre, it will be worth roughly $£ 1,000,000$ per annum to New Zealand. Capitalised at say 5 per cent. that would mean the nation would be justified in spending $£ 20,000,000$ to gain this increase in production.

I contend, therefore, that it will be profitable to 
New Zealand as a whole to lend money, free of interest, for land development.

According to the valuation of the land, the amount of loan per acre could be determined, and on the same basis it should be possible to fix the period for which no interest would be chargeable. The average man who attempts to develop a block of rough land cannot expect to get returns from it for some years. If he did not have to pay interest for, say, 3 to 5 years, it would enable him to proceed with development and still maintain a reasonable standard of living. Such a system of financing land development would necessitate the setting up of a new organisation, but probably the Marginal Lands Board could attend to this.

My thoughts on the matter are :-

1. That loans on easy terms should be available for land development work.

2. That a separate loan be granted for each section of the farm as and when its development is to commence.

3. That no interest be charged for say 3 to 5 years.

4. That interest should be at a low rate, say 1 per cent. in the first year that interest is payable and that the rate should increase by, say, $\frac{1}{2}$ per cent. per annum until the standard rate is reached. Under this system there would be an incentive for farmers to repay the loan as early as possible.

5. That loans of the kind suggested, should be granted for land development along approved lines, but that a minimum of irksome, restrictions be placed on the borrower..

Unless finance is made available on extremely easy terms, I cannot see how we can expect people with limited capital to make a success of developing rough, unproductive land.

In any policy which may be designed to encourage people to farm rough hill country successfully, it will be almost fatal to attempt settlement on small areas. It seems that the rougher the land, the greater will be the area that can be an economic farm unit. 